\title{
The Action of Cephaloridine with Cloxacillin or Methicillin against $\beta$-Lactamase- Producing Gram-negative Bacteria
}

\author{
By CYNTHIA H. O'CALLAGHAN AND P. W. MUGGLETON \\ Glaxo Research Ltd., Stoke Poges, Bucks. and Greenford, Middx.
}

(Accepted for publication 27 March 1967 )

\begin{abstract}
SUMMARY
Cephaloridine has a broad spectrum of antibacterial activity, but certain Gram-negative organisms (e.g. Aerobacter aerogenes, Proteus morgani) are resistant by reason of their ability to destroy the antibiotic. Methicillin and cloxacillin do not inhibit Gram-negative organisms but are resistant to the $\beta$ lactamases which some strains produce and can protect cephaloridine from destruction by such enzymes. This protection effect towards cephaloridine has been demonstrated in vitro and on experimentally infected mice. In vitro, a relatively small proportion of the penicillin exerted a maximal protecting effect towards cephalosporin and enhanced its bactericidal action against the Gramnegative organisms which produce $\beta$-lactamase. The clinical use of a combination of cloxacillin or methicillin with cephaloridine for the treatment of intractable systemic infections with $\beta$-lactamase-producing Gram-negative organisms is suggested, even though laboratory tests may show the organisms to be resistant to both cephaloridine and the penicillins when they are tested separately.
\end{abstract}

\section{INTRODUCTION}

Certain Gram-negative organisms such as strains of Aerobacter aerogenes and Proteus morgani (Muggleton, O'Callaghan \& Stevens, 1964) are not susceptible to the antibacterial action of cephaloridine (Ceporin; Glaxo Laboratories, Ltd.). Further investigation has shown that many of these organisms are able to decompose cephaloridine to a substance which has no antibacterial activity, due to destruction of the $\beta$-lactam ring. Fleming, Goldner \& Glass (1963) described a cephalosporinase able to decompose cephalosporin $\mathrm{C}$; they suggested that this was a $\beta$-lactamase, capable of opening the 4-membered ring. Ayliffe (1965), Hamilton-Miller, Smith \& Knox (I965) and Sabath, Jago \& Abraham (I965) described cephalosporinases from several Gramnegative species. These $\beta$-lactamases from Gram-negative organisms can decompose some penicillins, such as benzylpenicillin and ampicillin but not others, such as cloxacillin or methicillin. Cloxacillin and methicillin have no activity against the $\beta$-lactamase-producing Gram-negative organisms but protect other penicillins against decomposition by the enzymes (Hamilton-Miller, Smith \& Knox, 1964; Sutherland \& Batchelor, 1964). Hamilton-Miller et al. (1965) and Sabath, et al. (1965) extended this observation by showing that the presence of a non-susceptible penicillin would protect susceptible penicillins and cephaloridine from destruction by $\beta$-lactamases.

The activity of an antibiotic against an organism intrinsically sensitive to it will be decreased when the organism is able to destroy the substance. When destruction is 
rapid, complete insensitivity will result. Inhibition of the destructive ability of the organism may render it sensitive and treatment with the antibiotic may then be effective.

We have investigated the ability of cloxacillin and methicillin to protect cephaloridine against the destructive action of Gram-negative bacterial strains which produce $\beta$-lactamase. Our experiments were made with suspensions of living organisms rather than with killed organisms or isolated enzyme systems since we wished to reproduce the conditions which might apply in vivo. Thus enzyme induction could take place in our test system and multiplication of organisms would occur at antibiotic concentrations below the minimum inhibitory concentration, as they would in an infected animal. In this way the feasibility of improving the treatment of infections due to $\beta$-lactamase-producing Gram-negative organisms with cephaloridine could be assessed.

\section{METHODS}

Assay methods. The antibiotic activity of cephaloridine, alone or in the presence of cloxacillin or methicillin, was determined by large plate bioassay with Escherichia coli 573 as test organism. This organism is insensitive to the two penicillins used. Difco tryptose agar (with the addition of a $1 \cdot 25 \% \mathrm{w} / \mathrm{v}$, solution of tetrazolium chloride) was seeded with $0.01 \%(\mathrm{v} / \mathrm{v})$ of an overnight broth culture. Cloxacillin and methicillin were assayed with Staphylococcus aureus NCTC 7447 in the same medium; this organism is sensitive to cephaloridine, so that the penicillins could not be assayed when mixed with cephaloridine.

Estimation of cephaloridine-inactivating activity. We compared the abilities of a large number of organisms to destroy the antibacterial activity of cephaloridine at a concentration $250 \mu \mathrm{g} . / \mathrm{ml}$. Organisms from static broth cultures of various organisms grown at $37^{\circ}$ for $48 \mathrm{hr}$ were collected by centrifugation and then resuspended in one-tenth of their original volume of fresh nutrient broth. The suspensions were diluted in doubling series in $2 \mathrm{ml}$. nutrient broth in tubes; to each tube was added $2 \mathrm{ml}$. antibiotic solution, consisting of cephaloridine alone or with cephaloridine + inhibitor under test, so that each tube in a series contained $4 \mathrm{ml}$. organism suspension at a dilution up to $\mathrm{I} / 400,000$, together with $250 \mu \mathrm{g} . / \mathrm{ml}$. of each substance being tested. Except where otherwise stated, the antibiotics were kept at these concentrations. A final tube in any series contained the test solution only without organisms. The tubes were incubated at $37^{\circ}$ for $2 \mathrm{hr}$ and the residual cephaloridine was estimated by plate bioassay. From the assay results we calculated the dilution of organism suspension which destroyed $50 \%$ (usually $125 \mu \mathrm{g} / \mathrm{ml}$.) of the cephaloridine. We then calculated the amount of antibiotic that would theoretically have been destroyed by I $\mathrm{ml}$. of the undiluted suspension of organisms. The results (Tables I, 2, 3 and 5) are expressed in these terms. The method is similar to that used by Chang \& Weinstein (I963), but is more quantitative.

Most of the work was done with two organisms; one called Aerobacter aerogenes P99 has been subsequently identified by the Salmonella Reference Laboratory, Central Public Health Laboratory, Colindale, as Enterobacter cloacae and was given to us by Dr P. C. Fleming (Hospital for Sick Children, Toronto); the other was a strain of Proteus morgani, NCTC 235. A $48 \mathrm{hr}$ culture of $P$. morgani contained about $5 \times 10^{9}$ viable organisms and the $A$. aerogenes about $2 \times 10^{10}$ viable organisms. Both organisms tended to vary from day to day both in sensitivity to cephaloridine 
and in ability to destroy it; therefore the activity of any bacterial suspension against any substrate was always compared with its activity against cephaloridine in the same experiment. Accurate quantitative comparisons between different organisms were difficult under the test conditions used because, for example, A. aerogenes grew faster than $P$. morgani during the $2 \mathrm{hr}$ period of incubation.

Measurement of minimum inhibitory concentrations. Tube dilution tests (doubling dilutions) in nutrient broth inoculated with $0.05 \mathrm{ml}$. of a I/100 dilution of an overnight broth culture of the test organisms were used. Tests were read after incubation for $24 \mathrm{hr}$ at $37^{\circ}$.

Estimation of bactericidal action. Tubes of nutrient broth containing antibiotic mixtures were inoculated with $\mathrm{I} \%(\mathrm{v} / \mathrm{v})$ of a $\mathrm{I} / \mathrm{I} 00$ dilution of an overnight broth culture of Aerobacter aerogenes or Proteus morgani. The tubes were incubated at $37^{\circ}$ and small samples were withdrawn at intervals. Tenfold serial dilutions of the samples were plated in nutrient on agar in Petri dishes which were then incubated overnight at $37^{\circ}$. From the colony counts after incubation, the percentage kill of the organisms was calculated for each time of sampling, based on the viable count at 'Omin.'.

Estimation of serum binding. The extent to which the antibiotic substances were serum bound was estimated by an ultrafiltration method. Solutions of antibiotic $(50 \mu \mathrm{g} . / \mathrm{ml}$.) were prepared in undiluted horse serum (Burroughs Wellcome, no. 2). Part of each solution was ultrafiltered under Io lb./sq. in. pressure through Visking tubing. The filtrate collected was assayed and the amount which remained bound to the serum protein thus calculated.

Protection tests on experimentally infected mice. Groups of 5 to 8 mice were challenged with $5 \times 10^{8}$ organisms of Proteus morgani NCTC 235 in saline suspension prepared from overnight nutrient agar cultures. The groups were treated with serial doubling dilutions of cephaloridine, methicillin or cloxacillin by subcutaneous injection in $0.2 \mathrm{ml}$. of saline solution each animal being treated at $0 \cdot 5,4,8,24$ and $32 \mathrm{hr}$ after challenge; the highest dose was $400 \mathrm{mg} . / \mathrm{kg}$. Cephaloridine was also given with cloxacillin or methicillin at $200 \mathrm{mg} . / \mathrm{kg}$. dose of each, or $400 \mathrm{mg}$. $/ \mathrm{kg}$. dose of total antibiotic. A similar experiment was done with another virulent strain of $P$. morgani, P47. From the numbers of mice that survived on the fifth post-challenge day, the median effective doses (ED 50) were calculated. It was not possible to do protection tests with Aerobacter aerogenes $\mathrm{P} 99$ since this strain was not virulent to mice.

\section{RESULTS}

Ability of the test organisms to destroy different substrates

Suspensions of Aerobacter aerogenes P 99 and Proteus morgani NCTC 235 were incubated with different penicillins and cephalosporins; the results (Table I) indicated that these organisms were much more able to destroy the antibacterial activity of the cephalosporins than of the penicillins, the $A$. aerogenes strain being much more active than the $P$. morgani strain.

\section{Effect of cloxacillin or methicillin with cephaloridine in vitro}

The proportion of cloxacillin or methicillin required to protect cephaloridine $250 \mu \mathrm{g}$./ml. was determined. We estimated the amount of inactivation of cephaloridine which occurred when various amounts of the penicillins from $250 \mu \mathrm{g}$. to $4 \mu \mathrm{g} . / \mathrm{ml}$. were mixed with cephaloridine $250 \mu \mathrm{g}$. $/ \mathrm{ml}$. The tests were made in $0.01 \mathrm{M}$-phosphate buffer 
( $\mathrm{pH}_{7}{ }^{\circ}$ ) and in whole horse serum with Aerobacter aerogenes $\mathrm{P} 99$. The results (Table 2) indicated that methicillin and cloxacillin had a strong protective effect on the cephaloridine. Cloxacillin was more effective in phosphate buffer. When tested in serum, however, methicillin and cloxacillin were almost equal in effect, a probable result of the greater degree of serum-protein binding of the cloxacillin. In experiments on the serum binding of the penicillins, we found that of a $50 \mu \mathrm{g} . / \mathrm{ml}$. solution in whole serum, $5 \mathrm{I} \%$ of cloxacillin, but only $5.4 \%$ of methicillin, was bound.

\section{Table I. Destruction of penicillins and cephalosporins by Aerobacter aerogenes and Proteus morgani}

\begin{tabular}{|c|c|c|}
\hline \multirow[b]{2}{*}{ Substrate } & \multicolumn{2}{|c|}{$\begin{array}{c}\text { Amount ( } \mu \text { g.) destroyed in } 2 \\
\text { suspension of }\end{array}$} \\
\hline & A. aerogenes $\mathrm{P} 99$ & $\begin{array}{l}P . \text { morgani } \\
\text { NCTC } 235\end{array}$ \\
\hline Penicillin G & 33,300 & 25,400 \\
\hline Ampicillin & 2,300 & Nil \\
\hline Cloxacillin & Nil & Nil \\
\hline Methicillin & $\mathrm{Nil}$ & $\mathrm{Nil}$ \\
\hline Cephalosporin $\mathbf{C}$ & $>1,000,000$ & 104,500 \\
\hline Cephalothin & 500,000 & 40,000 \\
\hline Cephaloridine & $>1,000,000$ & 74,200 \\
\hline
\end{tabular}

Table 2. Effect of concentrations of cloxacillin or methicillin on the inactivation of cephaloridine by Aerobacter aerogenes in phosphate buffer $\left(\mathrm{pH}_{7} \mathrm{O}^{\circ}\right)$ or in horse serum

\begin{tabular}{|c|c|c|c|}
\hline \multirow{2}{*}{\multicolumn{2}{|c|}{$\begin{array}{l}\text { Concentrations of antibiotics } \\
(\mu \mathrm{g} . / \mathrm{ml} .)\end{array}$}} & \multicolumn{2}{|c|}{$\begin{array}{l}\text { Cephaloridine destroyed ( } \mu \mathrm{g} .) \text { in } 2 \mathrm{hr} \\
\text { I ml. of suspension of } A \text {. aerogenes }\end{array}$} \\
\hline & & \multirow[t]{2}{*}{ in $\mathrm{pH} 7.0$ buffer } & \multirow{2}{*}{ in horse serum } \\
\hline Cephaloridine & Cloxacillin & & \\
\hline 250 & - & $5,324,800$ & $1,600,000$ \\
\hline 250 & 250 & 984 & I I, 864 \\
\hline 250 & 62 & $I, 252$ & 77,312 \\
\hline 250 & $3 I$ & 3,584 & 150,528 \\
\hline 250 & 16 & 39,424 & Not tested \\
\hline 250 & 8 & 77,312 & 149,504 \\
\hline \multirow[t]{2}{*}{250} & 4 & I I I,6 I 6 & 589,824 \\
\hline & Methicillin & & \\
\hline 250 & 250 & 36,864 & 14,646 \\
\hline 250 & 62 & 71,168 & 76,800 \\
\hline 250 & 31 & 63,232 & 256,000 \\
\hline 250 & 16 & 274,432 & Not tested \\
\hline 250 & 8 & 131,072 & 424,960 \\
\hline 250 & 4 & 305,152 & 219,477 \\
\hline
\end{tabular}

A similar experiment was done in phosphate buffer only with Proteus morgani NCTC 235. This organism was much weaker than Aerobacter aerogenes $\mathbf{P} 99$ in its inactivating action (Table I). Only a very small proportion of cloxacillin or methicillin was required to protect the cephaloridine; cloxacillin, $5 \mu \mathrm{g} . / \mathrm{ml}$. was able completely to protect cephaloridine $250 \mu \mathrm{g}$. $/ \mathrm{ml}$. from destruction by $P$. morgani. Without cloxacillin, $96,000 \mu \mathrm{g}$. of cephaloridine were destroyed under the same test conditions.

Infrared spectroscopy of samples of cephaloridine after inactivation showed no evidence of a $\beta$-lactam ring. Samples were centrifuged and freeze dried for this test. 
Nuclear magnetic resonance measurements agreed with this and the loss of antibacterial activity was thought to be due most likely to the action of a $\beta$-lactamase which opened the $\beta$-lactam ring.

Experiments with other organisms, mainly strains of Aerobacter and Proteus freshly isolated from hospital patients, showed that organisms which were resistant to cephaloridine were, in general, able to inactivate cephaloridine rapidly, although there are exceptions. Sensitive strains of Escherichia coli and Proteus sp. were unable, under the conditions of the test, to inactivate cephaloridine. Examples are given in Table 3.

Table 3. Ability of various strains of Gram-negative organisms to destroy cephaloridine and the effect of cloxacillin

\begin{tabular}{|c|c|c|c|c|}
\hline \multirow[b]{2}{*}{ Organism } & \multirow[b]{2}{*}{$\begin{array}{l}\text { Strain } \\
\text { code }\end{array}$} & \multirow[b]{2}{*}{$\begin{array}{l}\text { Cephalo- } \\
\text { ridine } \\
\text { (m.i.c. } \\
\mu \mathrm{g} . / \mathrm{ml} .)\end{array}$} & \multicolumn{2}{|c|}{$\begin{array}{l}\text { Cephaloridine }(\mu \mathrm{g} . / \mathrm{ml} .) \text { de- } \\
\text { stroyed by I ml. suspension } \\
\text { when treated }\end{array}$} \\
\hline & & & alone & $\begin{array}{l}\text { in presence of } \\
\text { cloxacillin } \\
(\mathrm{I}: \mathrm{I})\end{array}$ \\
\hline Aerobacter aerogenes & $\begin{array}{l}\text { P } 99 \\
30^{*} \\
44^{*}\end{array}$ & $\begin{array}{r}500 \\
250 \\
250\end{array}$ & $\begin{array}{r}1,344,000 \\
9,090 \\
655,400\end{array}$ & $\begin{array}{c}8,830 \\
\mathrm{Nil} \\
25,408\end{array}$ \\
\hline Proteus morgani & $\begin{array}{c}\text { NCTC } 235 \\
47 \dagger+ \\
1 \dagger \\
2 \dagger+ \\
3 * \dagger\end{array}$ & $\begin{array}{l}250 \\
500 \\
125 \\
125 \\
125\end{array}$ & $\begin{array}{r}33,790 \\
250,770 \\
37,630 \\
39,930 \\
79,870\end{array}$ & $\begin{array}{l}\text { Nil } \\
\text { Nil } \\
\text { Nil } \\
\text { Nil } \\
\text { Nil }\end{array}$ \\
\hline P. vulgaris & $43 * \dagger$ & 250 & 253,950 & 5,630 \\
\hline$P$. rettgeri & $19^{*} \dagger$ & 250 & 327,680 & 29,950 \\
\hline Escherichia coli & 573 & 8 & Nil & Nil \\
\hline $\begin{array}{l}\text { Klebsiella pneumoniae } \\
P . \text { pyocyanea (aeruginosa) }\end{array}$ & $\begin{array}{c}431+ \\
2 * \ddagger \\
14 * \ddagger \\
\text { LAUSANNE } \\
\text { NCTC } 8203\end{array}$ & $\begin{array}{c}\text { I6 } \\
8 \\
8 \\
250 \\
>4,000\end{array}$ & $\begin{array}{l}\text { Nil } \\
\text { Nil } \\
\text { Nil } \\
\text { Nil } \\
\text { Nil }\end{array}$ & $\begin{array}{l}\text { Nil } \\
\text { Nil } \\
\text { Nil } \\
\text { Nil } \\
\text { Nil }\end{array}$ \\
\hline
\end{tabular}

In vitro antibacterial activity of cephaloridine alone and with cloxacillin or methicillin

Minimum inhibitory concentrations (m.i.c.) of cephaloridine in various proportions with cloxacillin or methicillin were measured for several strains of Aerobacter aerogenes, Proteus morgani and one strain of Klebsiella pneumoniae. The results (Table 4), indicated that cloxacillin or methicillin, added to cephaloridine, considerably increased its activity against $\beta$-lactamase-producing Gram-negative organisms. Cloxacillin was more effective than methicillin. With Klebsiella pneumoniae (LAUSANNE), cloxacillin with cephaloridine was not more inhibitory than cephaloridine alone. This strain does not destroy cephaloridine (Table 3) and must therefore be relatively resistant to it by some other mechanism.

The bactericidal action of cephaloridine with cloxacillin or methicillin

Cephaloridine is bactericidal to many organisms at concentrations very close to the m.i.c. value (O'Callaghan \& Marshall, I965). We tested the bactericidal action of 
cephaloridine alone and in $\mathrm{I}+\mathrm{I}$ mixtures with cloxacillin and methicillin against Aerobacter aerogenes $\mathrm{P} 99$ and Proteus morgani NCTC 235. The results (Figs. 1, 2) showed that, whilst none of the antibiotics was bactericidal at the concentrations tested when used alone, a mixture of cephaloridine with either cloxacillin or methicillin killed the

Table 4. Effects of cloxacillin or methicillin on the minimum inhibitory concentrations of cephaloridine against $\beta$-lactamase-producing Gram-negative bacteria

Minimum inhibitory concentration of cephaloridine $(\mu \mathrm{g} . / \mathrm{ml}$.$) in mixtures$

Test organism

Proteus morgani $63 / 63$

$P$. morgani 487

$P$. morgani NCTC 235

Aerobacter aerogenes P 99

$A$. aerogenes 30

Klebsiella pneumoniae

(LAUSANNE)*

P. morgani $63 / 63$

P. morgani 487

A. aerogenes $\mathrm{P} 99$

$A$. aerogenes 30

Proportion of cephaloridine:cloxacillin

$\begin{array}{rrrrr}8: 8 & 8: 4 & 8: 2 & 8: 1 & 8: 0 \\ 16 & 32 & 62 & 125 & 500 \\ 32 & 32 & 125 & 125 & 1000 \\ 16 & 16 & 32 & 61 & 500 \\ 125 & 125 & 125 & 250 & 1000 \\ 8 & 8 & 16 & 16 & 62 \\ 125 & \text { nt } & \text { nt } & \text { nt } & 125\end{array}$

Proportion of cephaloridine to methicillin

$\begin{array}{rrrrr}8: 8 & 8: 4 & 8: 2 & 8: 1 & 8: 0 \\ 62 & 125 & 125 & 125 & 500 \\ 125 & 250 & 250 & 250 & 1000 \\ 250 & 500 & 500 & 2000 & 2000 \\ 62 & 62 & 125 & 125 & 250\end{array}$

$\mathrm{nt}=$ not tested, ${ }^{*}=$ non- $\beta$-lactamase producing organism.

organisms rapidly. Thus, for example, the m.i.c. for $P$. morgani was $500 \mu \mathrm{g} . / \mathrm{ml}$. with cephaloridine and $1000 \mu \mathrm{g} . / \mathrm{ml}$. with cloxacillin and the cultures grew unimpeded with either at $3 \mathrm{I} \mu \mathrm{g}$. $/ \mathrm{ml}$. but a mixture of both at $16 \mu \mathrm{g} . / \mathrm{ml}$. killed more than $90 \%$ of the organisms in $3 \mathrm{hr}$; there was no recovery at $24 \mathrm{hr}$. With the highly resistant strain of $A$. aerogenes, the effect was even more marked. The culture grew normally in $250 \mu \mathrm{g}$. $/ \mathrm{ml}$. of either cloxacillin or cephaloridine alone, but together at $125 \mu \mathrm{g} . / \mathrm{ml}$. of each there was a rapid kill without any recovery at $24 \mathrm{hr}$. Similar results were obtained with methicillin in place of cloxacillin, but the rate of kill was somewhat slower with these mixtures than with cephaloridine + cloxacillin.

\section{Effect of cloxacillin and methicillin on the $\beta$-lactamase production of Gram-negative bacteria}

Aerobacter aerogenes $\mathrm{P} 99$ and Proteus morgani NCTC 235 were grown for four serial transfers in broth containing cloxacillin $250 \mu \mathrm{g} . / \mathrm{ml}$. About half the cloxacillin remained after $24 \mathrm{hr}$ incubation in the supernatant broth; this was separated from the organisms by centrifuging. Organisms from the cultures at each transfer were tested for ability to destroy cephaloridine as described before. Organisms from parallel cultures grown in the absence of cloxacillin were tested as controls. No cloxacillin was added when the organisms were tested. The $A$. aerogenes organisms grown in the presence of cloxacillin were much less able to destroy cephaloridine than were the control organisms grown without it. The decrease in activity was I0- to 50-fold, which 
was well outside the range of the variation of the controls although we could not rule out the possibility that some remaining cloxacillin was being transferred with the organisms. Aerobacter aerogenes organisms were, however, still capable of producing $\beta$-lactamase after four serial subcultures in the presence of methicillin (Table 5).

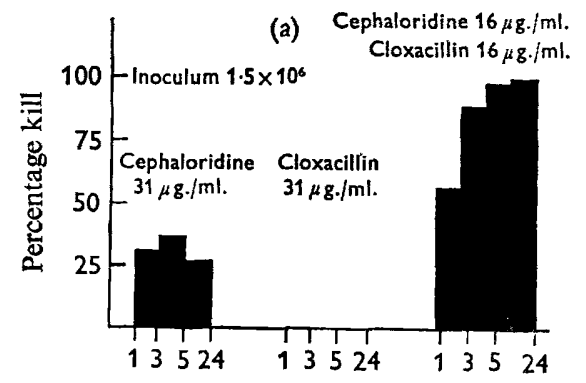

Time of exposure to antibiotic (hr)

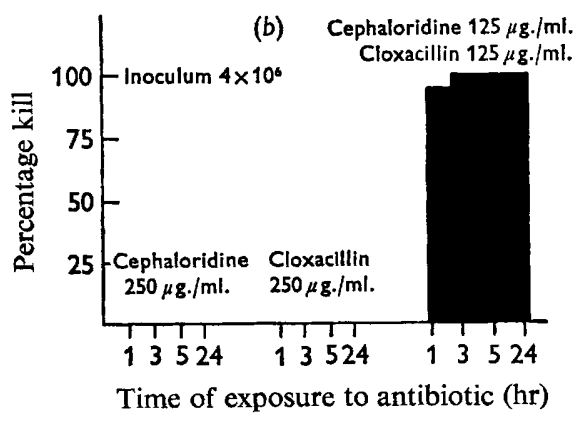

Fig. I. Bactericidal effects of cephaloridine and cloxacillin, separately and combined;

(a) $P$. morgani NCTC $235 ;(b) A$. aerogenes $\mathrm{P} 99$.
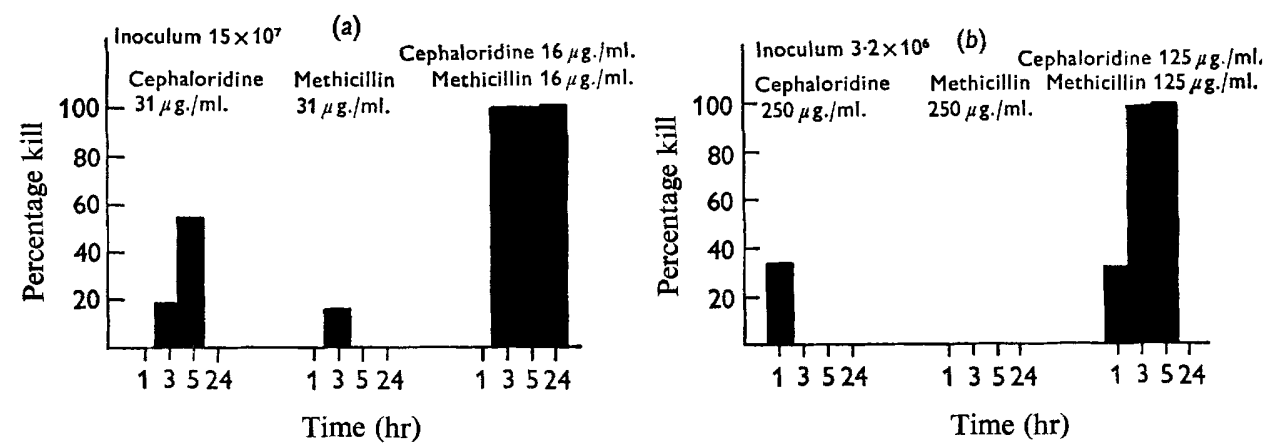

Fig. 2. Bactericidal effects of cephaloridine and methicillin, separately and combined;

(a) P. morgani NCTC 235; (b) A. aerogenes $\mathbf{P} 99$.

Proteus morgani organisms grown in serial subculture in medium containing cloxacillin $250 \mu \mathrm{g} . / \mathrm{ml}$. were also almost entirely unable to destroy cephaloridine, with a decrease of over 500-fold in $\beta$-lactomase activity over the controls. Their destructive ability was restored in full by one further subculture in the absence of the penicillin. A similar experiment with methicillin was not possible with this strain since it did not grow in the presence of methicillin at concentrations above $32 \mu \mathrm{g} . / \mathrm{ml}$.

\section{Resistance development}

Proteus morgani NCTC 235 was serially subcultivated in cephaloridine alone or in I + I mixture with cloxacillin (Table 6). The strain of $P$. morgani used was more sensitive (m.i.c. $3 \mathrm{I} \mu \mathrm{g} . / \mathrm{ml}$ ) to cephaloridine than we had seen previously. Over sixteen transfers in the presence of cephaloridine alone, it increased slowly in resistance to an m.i.c. of $1000 \mu \mathrm{g}$. $/ \mathrm{ml}$. In the parallel experiment with a $\mathrm{I}+\mathrm{I}$ mixture of cephaloridine + cloxacillin, the strain was initially sensitive to cephaloridine $2 \mu \mathrm{g} . / \mathrm{ml}$. (in the presence of $2 \mu \mathrm{g}$. $/ \mathrm{ml}$. also of cloxacillin). During subcultivation, resistance in- 
creased slowly in stepwise amounts at a rate similar to that with cephaloridine alone. After the sixteen subcultivations in the mixture the culture was still sixteen times more sensitive to cephaloridine in the I + I mixture with cloxacillin than it was when it had been subcultivated in cephaloridine alone. It thus appeared that whereas the resistance of the culture had increased during subcultivation in the cephaloridine + cloxacillin mixture, the cephaloridine-destroying enzyme could still be inhibited with cloxacillin.

Table 5. Comparison of $\beta$-lactamase produced by organisms grown in the presence or absence of cloxacillin

Amount of cephaloridine in $\mu \mathrm{g}$. destroyed in $2 \mathrm{hr}$ by $\mathrm{I} \mathrm{ml}$. suspension of

\begin{tabular}{|c|c|c|c|c|}
\hline \multirow[b]{2}{*}{$\begin{array}{c}\text { Transfer } \\
\text { no. }\end{array}$} & \multicolumn{2}{|c|}{ Aerobacter aerogenes Р 99} & \multicolumn{2}{|c|}{ Proteus morgani NCTC 235} \\
\hline & $\begin{array}{l}\text { Cloxacillin } \\
\text { culture }\end{array}$ & $\begin{array}{l}\text { Normal } \\
\text { culture }\end{array}$ & $\begin{array}{l}\text { Cloxacillin } \\
\text { culture }\end{array}$ & $\begin{array}{l}\text { Normal } \\
\text { culture }\end{array}$ \\
\hline $\mathbf{I}$ & 160,800 & $3,584,000$ & Nil & 92,200 \\
\hline 2 & 138,200 & $7,680,000$ & Nil & 215,000 \\
\hline 3 & 56,300 & $6,45 \mathrm{I}, 000$ & 500 & 286,700 \\
\hline 4 & 256,000 & $7,885,000$ & Nil & 770,000 \\
\hline \multicolumn{5}{|c|}{ Subculturing continued but no cloxacillin now added } \\
\hline 5 & $>2,000,000$ & $13,517,000$ & 778,200 & 635,400 \\
\hline \multirow[t]{2}{*}{6} & $>2,000,000$ & $9,523,000$ & 491,520 & 573,400 \\
\hline & $\begin{array}{l}\text { Methicillin } \\
\text { culture }\end{array}$ & $\begin{array}{l}\text { Normal } \\
\text { culture }\end{array}$ & $\begin{array}{l}\text { Methicillin } \\
\text { culture }\end{array}$ & $\begin{array}{l}\text { Normal } \\
\text { culture }\end{array}$ \\
\hline $\mathbf{I}$ & I,254,400 & I,984,000 & - & - \\
\hline 2 & $6,225,900$ & $5,785,600$ & - & - \\
\hline 3 & $1,939,200$ & 800,000 & - & - \\
\hline 4 & $1,984,000$ & 729,600 & - & - \\
\hline \multicolumn{5}{|c|}{ Subculturing continued but no methicillin now added } \\
\hline 5 & $\mathbf{I}, 8 \mathrm{I} 7,600$ & $3,174,400$ & - & - \\
\hline 6 & $1,299,200$ & $\mathrm{I}, 049,600$ & - & - \\
\hline & & $-=\operatorname{not} t$ & & \\
\hline
\end{tabular}

Table 6. Resistance development of Proteus morgani NCTC 235 to cephaloridine and to cephaloridine + cloxacillin, $1+1$

\begin{tabular}{|c|c|c|c|c|c|}
\hline \multirow[b]{2}{*}{ Antibiotic } & \multicolumn{5}{|c|}{ M.i.c. $(\mu \mathrm{g} . / \mathrm{ml}$.$) at transfer$} \\
\hline & I & 4 & 8 & 12 & 16 \\
\hline Cephaloridine & $3 I$ & 62 & 125 & I 25 & 1000 \\
\hline $\begin{array}{l}\text { Cephaloridine }+ \\
\text { cloxacillin, I + I (total wt.) }\end{array}$ & 4 & 8 & $3 I$ & $3 I$ & 62 \\
\hline
\end{tabular}

Protection tests on experimentally infected mice

With Proteus morgani NCTC 235, the minimum lethal dose was about $\mathrm{I} \times 10^{8}$ organisms when given intraperitoneally. A challenge of $5 \times 10^{8}$ organisms killed the mice in $24 \mathrm{hr}$, before which time large numbers of organisms were recovered from the heart blood. Serum taken from such mice $6 \mathrm{hr}$ after giving the challenge dose rapidly inactivated substantial amounts of cephaloridine. The results from different protection tests with the cephaloridine + cloxacillin or + methicillin mixtures varied from experi- 
ment to experiment, possibly because the amounts of $\beta$-lactamase produced by the challenge organisms in vivo differed from test to test. Nevertheless, the mixtures of cephaloridine with either methicillin or cloxacillin were much more effective in protecting the mice than could be explained by a simple additive effect. Typical results are shown in Table 7. Statistical analysis of the results from the experiment summarized in Table 7, using logit transformation, showed that with $P$. morgani NCTC 235, the ED 50 dose of $30.5 \mathrm{mg} . / \mathrm{kg}$. of cephaloridine: cloxacillin had $95 \%$ confidence limits of I4-58 while the ED 50 of 24.5 for the cephaloridine + methicillin had limits of $12.0-$ 48.5. The improvements in performance over the antibiotic components tested separately was thus highly significant.

Table 7. Tests on experimentally infected mice with cephaloridine alone and with cloxacillin or methicillin

\begin{tabular}{|c|c|c|}
\hline \multirow[b]{2}{*}{ Treatment } & \multicolumn{2}{|c|}{ ED 50 dose of total antibiotic in $\mathrm{mg} . / \mathrm{kg}$. } \\
\hline & $\begin{array}{l}\text { Proteus morgani } \\
\text { NCTC } 235\end{array}$ & $\begin{array}{l}\text { P. morgani } \\
\text { P } 47\end{array}$ \\
\hline Cephaloridine alone & $>400$ & About 150 \\
\hline Cloxacillin alone & $>400$ & $>400$ \\
\hline $\begin{array}{l}\text { Cephaloridine }+ \text { cloxacillin } \\
(I+I)\end{array}$ & $30 \cdot 5$ & About 44 \\
\hline Cephaloridine alone & $>400$ & About 150 \\
\hline Methicillin alone & $>400$ & $>400$ \\
\hline $\begin{array}{l}\text { Cephaloridine + methicillin } \\
(\mathrm{I}+\mathrm{I})\end{array}$ & $24 \cdot 5$ & About 65 \\
\hline
\end{tabular}

Table 8. Protection tests with Proteus morgani NCTC 235

The effect of varying the proportions of the antibiotic mixtures

Treatment

Cephaloridine alone

Cloxacillin alone

Cephaloridine + cloxacillin $(I+I)$

Cephaloridine + cloxacillin $(\mathrm{I}+4)$

Cephaloridine alone

Methicillin alone

Cephaloridine + methicillin $(2+I)$

Cephaloridine + methicillin $(I+I)$

Cephaloridine + methicillin $(\mathrm{I}+2)$

\begin{tabular}{|c|c|}
\hline \multicolumn{2}{|c|}{ ED 50 dose (mg./kg.) } \\
\hline Total antibiotic & Cephaloridine \\
\hline 100 & 100 \\
\hline$>100$ & - \\
\hline I6.6 & $8 \cdot 8$ \\
\hline 15.0 & $3 \cdot 0$ \\
\hline 35 & 35 \\
\hline 44 & 一 \\
\hline I 4.4 & $9 \cdot 6$ \\
\hline$>\mathrm{I} 2.5$ & $>6.0$ \\
\hline I 5.0 & $3 \cdot 0$ \\
\hline
\end{tabular}

(Note. The two parts of the experiment, with cloxacillin and methicillin, respectively, in the above table were done on different occasions.)

It was possible that a I + I mixture of cephaloridine with cloxacillin was not optimal for protecting the animals. An experiment with the same conditions as before, to compare various proportions of the antibiotics, was done with groups of eight mice. The results are given in Table 8 . The results showed that whilst variation of the proportions of cephaloridine to cloxacillin from $\mathrm{I}+\mathrm{I}$ to $\mathrm{I}+4$ affected the amount of cephaloridine needed to protect the animals, the total weight of antibiotic mixture required remained constant. A similar effect was seen with cephaloridine + methicillin mixtures. The proportions of the components of the mixture thus did not appear to be critical. 


\section{DISCUSSION}

Cephaloridine has a broad spectrum of antibacterial activity and many common Gram-negative bacteria are sensitive to it. Some however are resistant, and in many instances this can be related to the ability of the organisms to inactivate the antibiotic. There seems little doubt that the mechanism of inactivation is the destruction of the $\beta$-lactam ring by a $\beta$-lactamase. This supposition is consistent with our observations in which we have seen alterations in the infrared spectrum and nuclear magnetic resonance of the inactivated antibiotic, which are indicative of destruction of the $\beta$-lactam ring, and also with the observations of other workers referred to earlier.

Cloxacillin and methicillin are known to possess a greater affinity for $\beta$-lactamase from Gram-negative organisms than other penicillins and cephalosporins. These compounds are not inactivated by the enzyme, despite which they have no activity against the organisms which produce it. In our work, we have found that mixtures of methicillin or cloxacillin with cephaloridine are able to protect the cephalosporin from inactivation by $\beta$-lactamase-producing Gram-negative organisms and the mixtures are then active inhibitors of the bacteria. In contrast, we have found that the addition of methicillin or cloxacillin does not increase the activity of cephaloridine against Gram-negative organisms which do not produce $\beta$-lactamase, a finding which adds support to the enzyme inhibition hypothesis. Our in vitro studies showed that when cephaloridine was protected from enzyme attack by admixture with the penicillins, it was bactericidal. Organisms such as Proteus morgani which were not killed by either the penicillins or by cephaloridine were killed rapidly by concentrations of the two substances together which could be reached in vivo at a site of infection.

In our in vitro tests, we found that the cephaloridine + methicillin mixtures were rather less active than the cephaloridine + cloxacillin ones when these were tested in broth. When tested in serum, however, cloxacillin was slightly less efficient in its protective activity so that methicillin became equally effective. We believe this to be due to the fact that cloxacillin is more highly serum-bound than is methicillin; when the mixtures were tested in vivo this hypothesis was upheld by the finding that the two penicillins were of approximately equal effect.

Despite the promising findings from our in vitro experiments, the possibility remained that the protective phenomenon would not work in infected animals. Appropriate concentrations of cephaloridine + the protective penicillin would have to be present at the infection site at the same time and this may be difficult to achieve. Our tests on experimentally infected mice have shown, however, that in the type of infection we used, cephaloridine was made effective by the concurrent administration of the $\beta$-lactamase-inhibiting penicillin. Moreover, the proportions of the cephaloridine and inhibitor administered were not very critical.

Repeated daily transfers in broth containing just subinhibitory concentrations of cephaloridine alone or of cephaloridine + penicillin mixtures resulted in the development of some intrinsic resistance to the cephaloridine. This was apparently not due to increased production of $\beta$-lactamase, since the effect of cloxacillin on the minimum inhibitory concentration of cephaloridine remained in the same proportion after sixteen subcultures as it had been at the first subculture. This is in agreement with the results of Barber \& Waterworth (1964) who showed that when strains of Proteus mirabilis sensitive to cephaloridine were exposed to this antibiotic in serial subculture, a slow 
stepwise increase in resistance occurred. These organisms had not, however, acquired resistance by developing an enzyme able to destroy cephaloridine.

With Pseudomonas pyocyanea (aeruginosa), an organism resistant to cephaloridine, Sabath, Jago \& Abraham (I965) showed that strain NCTC 8203 produced a cell-bound inducible $\beta$-lactamase which was inhibited by methicillin and cloxacillin. In experiments in our laboratory with 45 strains of $P$. pyocyanea isolated from clinical cases, we have found by our in vitro method that organisms of these strains only slowly inactivate very small amounts of cephaloridine, particularly when they have not previously been exposed to a substance such as a penicillin which could cause $\beta$-lactamase induction. It therefore seems to us that the mechanism of resistance in this case is much less dependent on a $\beta$-lactamase, and that the organisms themselves are intrinsically far more resistant. It is possible, however, that in conditions where very high concentrations of antibiotics can be achieved, e.g. in the urine, treatment of $P$. pyocyanea infections with such synergistic mixtures may be successful. One case has been reported by Shirley \& Moore (I965) using a mixture of benzylpenicillin and methicillin. Sabath, Elder, McCall, Steigbigel \& Finland (1966) have reported the successful treatment of human urinary tract infections due to $P$. pyocyanea, and also to a Proteus species and Escherichia coli, by using mixtures of cloxacillin and ampicillin. Cloxacillin exerts a similar protective effect with ampicillin as it does with cephaloridine. The protective effects of cloxacillin and methicillin apply only to $\beta$-lactamase-producing Gram-negative organisms. The action of $\beta$-lactamase produced by penicillin-resistant Staphylococcus aureus is unimpaired by either cloxacillin or methicillin, despite the resistance of these penicillins themselves to the action of the enzyme.

The authors thank Mrs W. B. Barber, Mr M. J. Basker, Miss J. Green, Miss S. M. Kirby, Miss P. Nash and Mr D. M. Ryan for technical assistance with the investigation reported here. The authors are grateful to Dr P. C. Fleming (Children's Hospital, Toronto), Professor S. Lambin (School of Pharmacy, University of Paris), Dr K. B. Rogers (The Children's Hospital, Birmingham) and Miss P. Waterworth (Royal Postgraduate Medical School, London) for bacterial cultures.

\section{REFERENCES}

Ayliffe, G. A. J. (1965). Cephalosporinase and penicillinase activity of gram-negative bacteria. J. gen. Microbiol. 40, I19,

Barber, M. \& Waterworth, P. M. (1964). Penicillinase resistant penicillins and cephalosporins. Br. med. J. 2, 344.

Chang, T. W. \& Weinstein, L. (1963). Isolation, characterisation and distribution of cephalosporinase. Antimicrobial Agents and Chemotherapy, p. 278. Publ. American Soc. Microbiol.

Fleming, P. C., Goldner, H. \& Glass, D. G. (1963). Observations on the nature, distribution and significance of cephalosporinase. Lancet $\mathbf{I}, \mathbf{I} 399$.

Hamilton-Miller, J. M. T., SMITh, J. T. \& KNox, R. (1964). Effect of penicillinase on the action of penicillins. Potentiation of penicillin action by inhibition of penicillinase. Nature, Lond. 20x, 867.

Hamilton-Miller, J. M. T., Smith, J. T. \& Knox, R. (1965). Interaction of cephaloridine with penicillinase producing gram-negative bacteria. Nature, Lond. 208, 235.

Muggleton, P. W., O’Callaghan, C. H. \& Stevens, W. K. (1964). Laboratory evaluation of a new antibiotic-cephaloridine (Ceporin). Br. med. J. 2, 1234.

O'Callaghan, C. H. \& Marshall, M. J. (I965). The bactericidal properties of cephaloridine (Ceporin). J. gen. Microbiol. 39, iv. 
SABATH, L. D., JAGo, M. \& ABraham, E. P. (1965). Cephalosporinase and penicillinase activities of a $\beta$-lactamase from Pseudomonas pyocyanea. Biochem. J. 96, 739.

Sabath, L. D., Elder, H. A., McCall, C. E., Steigbigel, N. H. \& Finland, M. (i966). Synergistic penicillin combinations in the treatment of human urinary tract infections. Abstracts of papers, 6th Interscience Conference on Antimicrobial Agents and Chemotherapy, Philadelphia, U.S.A.

Shirley, R. L. \& Moore, J. W. (1965). Pseudomonas aeruginosa urinary tract infection. New Engl. J. Med. 273, 283.

Sutherland, R. \& Batchelor, F. R. (1964). Synergistic activity of penillins against penicillinaseproducing gram-negative bacilli. Nature, Lond. $201,868$. 